\title{
Do State Accountancy Boards Diligently Exercise Their Disciplinary Powers?
}

\author{
Gary Colbert, University of Colorado at Denver \\ Dennis Murray, University of Colorado at Denver \\ Ronald Reed, (Email: Ronald.Reed@unco.edu), University of Northern Colorado
}

\begin{abstract}
Certified public accountants (CPAs), similar to many other professionals, are regulated by the individual jurisdictions within the United States. State accountancy boards issue licenses, which enable CPAs to offer their services to the public. In addition to issuing licenses only to qualified applicants, state boards help protect the public by disciplining CPAs who violate provisions of their state accountancy laws. This paper investigates the diligence with which state boards exercise their disciplinary powers. We identified 73 CPAs who were disciplined by the Securities and Exchange Commission between 1996 and 1998. State boards acted in 59 (80.8 percent) of these cases. Overall, we conclude that state boards appear to be exercising their disciplinary powers in those cases where the SEC has disciplined a CPA. Protection of the public appears to be a priority for many boards. There is some evidence, however, that for a few boards their disciplinary efforts could be more forcefully exercised.
\end{abstract}

\section{INTRODUCTION}

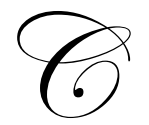

ertified public accountants (CPAs) are regulated by the accountancy boards of the individual jurisdictions within the United States, by the Securities and Exchange Commission (SEC) and by selfregulatory mechanisms, such as the American Institute of CPAs (AICPA) and various state societies of CPAs. It is the state accountancy boards that take the most fundamental and perhaps most important regulatory actions. These boards are empowered to issue and revoke a CPA's license. Such actions determine who can offer public accountancy services to the public and who cannot. While the SEC can bar a CPA from practicing before it, the SEC does not have the power to issue or revoke a license. The most severe action the AICPA or a state society can take is termination of membership. Therefore, the effective functioning of state accountancy boards is the cornerstone of ensuring that only qualified individuals are permitted to practice as CPAs.

Prior research has investigated the determinants and effectiveness of various state accountancy board regulations (e.g., Colbert and Murray 1998, Roberts and Kurtenbach 1998, and Young 1988, 1991). However, research that has addressed the extent to which state boards exercise their disciplinary powers (i.e., enforce existing regulations) has been sparse. Loeb (1972) examined charges processed by one state board during the period 1913 through 1969. Sixty-two percent of those charges were for advertising or solicitation violations, suggesting that the results of that study are not particularly relevant today. Schaefer and Welker (1994) examined the disciplinary activities of six state boards during various sub-periods in the 1980s. Their analysis of state board activities was primarily descriptive. Colbert and O'Keefe (1995) examined the results of Oregon's positive enforcement program, a program designed to routinely evaluate and enforce compliance with generally accepted auditing standards (GAAS). They found that sub-standard compliance with GAAS declined in the later years of their study. This decline was associated with an increase in the severity of the sanctions imposed by the board, suggesting that board sanctions do matter.

None of these studies attempted to ascertain if the boards were taking actions in situations were they should act. In other words, the studies were not based on an external referent that could validate the need for action. 
Accordingly, inferences cannot be drawn regarding whether the boards are imposing sanctions in all the situations where they should.

Some concerns have recently been expressed about the ability of state accountancy boards to exercise their disciplinary powers. For example, in the wake of the Enron and Arthur Andersen disclosures, a Wall Street Journal article noted that the Texas accountancy board has five lawyers and an investigation budget of $\$ 550,000$ (Gold, 2002). A serious question exists as to whether state boards have the resources to conduct investigations and to impose appropriate sanctions in large, high profile cases. Informal discussions with state boards' staff and SEC staff suggest that budgetary constraints limit the scope and depth of board enforcement activity.

This paper reports the results of a study designed to assess the degree to which state accountancy boards discipline CPAs that have been sanctioned by the SEC. Enforcement actions by the SEC indicate that, based upon its investigation, the SEC has concluded the CPA has violated some aspect of the securities law. One would expect that responsible state boards would assess if these CPAs also violated any state accountancy law. Considerable overlap exists between the federal securities laws and the accountancy laws of many states. For example, both sets of laws usually prohibit fraudulent acts and require auditors to adhere to GAAS. Given this overlap, one would expect state boards to discipline a large percentage of the CPAs sanctioned by the SEC.

The SEC announces the results of their investigations and the associated sanctions in its Accounting and Auditing Enforcement Releases (AAERs). We examined all AAERs in the period 1996-1998, and found that state boards disciplined 80.8 percent of the CPAs in our sample who were sanctioned by the SEC. However, we also found evidence that a few boards failed to act in cases where the SEC found fraudulent behavior, and in cases where the violation of state law was obvious.

This paper is organized as follows. The next section describes the SEC's investigational procedures. The third section describes the usual disciplinary powers of state accountancy boards. The fourth section describes the sample and results. The final section draws some conclusions and implications.

\section{INVESTIGATIONS BY THE SEC}

Firms with more than $\$ 10$ million dollars in assets or more than 500 shareholders must file periodic reports with the SEC. The SEC determines the form and content of these reports. Annual financial statements and supplemental schedules included in 10-K reports must be certified by a firm of independent CPAs. Registration statements, which are required to be filed prior to the public sale of securities, also contain certified financial statements.

Accounting related enforcement actions can target the registrant (i.e., the corporation), employees, officers and directors of the registrant and other parties associated with the registrant (e.g., auditors). Given that state accountancy boards have jurisdiction only over CPAs, our study did not examine alleged violations by corporations and non-CPA employees, officers and directors.

The SEC can bring charges under the fraud provisions of the Securities Exchange Acts of 1933 and 1934 when it believes that intentional material misstatements were made. It can also bring non-fraud charges under the reporting sections of the Acts, as well as charge auditors with violations of GAAS. The SEC staff believes that fraud charges are clearly the more serious. We have accordingly partitioned our sample into fraud and non-fraud cases for many of the analyses.

The SEC obtains information for enforcement actions from its market surveillance activities, reviews of financial statements, press reports, investor complaints, and referrals from other regulatory and governmental organizations. The SEC can bring action in a federal court or internally before an administrative law judge. This choice is based on the seriousness of the matter, the degree to which the issue is a highly technical one, the remedy or sanction sought and other factors. Situations frequently call for both types of proceedings. 
Courts can issue injunctions, which prohibit future violations of securities law. Such future violations could result in further fines or imprisonment. Courts can also impose fines, require the return of illegal profits, and bar individuals from acting as an officer or director of a publicly held corporation. Administrative proceedings can result in cease and desist orders, fines, return of illegal profits and barring individuals from practicing before the SEC. Targets of investigations often settle the charges without admitting or denying guilt.

The results of an accounting related enforcement action are summarized in an AAER. An AAER typically describes the alleged wrongdoing, identifies the violators, indicates the finding and sanction, and discloses if the target had agreed to a settlement. AAERs are public information. AAER results are also communicated directly to state boards via a letter from the SEC.

\section{STATE ACCOUNTANCY LAWS}

The Uniform Accountancy Act (AICPA/NASBA 1999) is intended to serve as a model act for state accountancy laws. Because this act can provide a general understanding of state accountancy laws, its major provisions regarding disciplinary actions are described below. ${ }^{1}$

Boards can invoke their disciplinary powers in response to a number of violations, including fraud or deceit in obtaining a license, revocation of a license or privileges in another state, revocation or suspension of the right to practice before any state or federal agency, dishonesty, fraud or gross negligence in the performance of services, violation of any provision of the accountancy act (including violations of professional standards and rules of professional conduct), conviction of a felony, performance of a fraudulent act and conduct reflecting adversely upon the licensee's fitness to perform services.

Boards have the power to revoke, suspend, or refuse to renew a license. They may reprimand, censure, or limit the scope of practice of any licensee. Boards may also put any licensee on probation and impose a fine (or proceeding costs). They may also require a peer review or satisfactory completion of a continuing professional education program. Thus, the penalties a board can impose are quite wide-ranging, and include license revocation. Since revocation precludes the licensee from practicing his or her profession, it can reasonably be viewed as the ultimate penalty that a board can impose.

Boards can impose penalties only after following appropriate procedures. Upon receipt of a complaint or other information suggesting a violation of the public accountancy law by a licensee, a board may, at its discretion, conduct an investigation. If the board issues a finding of probable cause, the board issues a complaint stating the charges and setting a time and place for a hearing before the board. The licensee against whom the complaint has been filed has a reasonable opportunity to examine all related evidence. The investigating officer presents evidence during the hearing and questions witnesses. The respondent licensee may be represented by counsel, can present evidence and question witnesses. A majority vote of board members then in office is required to sustain any charge.

\section{SAMPLE}

Table 1 summarizes the sample selection process. We examined the 250 AAERs issued by the SEC during the period $1996-1998 .{ }^{2,3}$ This period was selected to ensure that state boards had ample time to act on the findings of an AAER prior to us contacting them in May 2002. One hundred thirty-eight AAERs did not contain allegations against CPAs. For example, a number of AAERs focused on corporations or non-CPA employees of a corporation. Eliminating these AAERs yielded 112 AAERs that did sanction CPAs. We identified 27 instances where multiple AAERs addressed the same violation and 25 AAERs that did not identify the state in which the CPA was licensed. ${ }^{4}$ Eliminating these 52 AAERs resulted in a final sample of 60 AAERs. 


\begin{tabular}{|c|c|c|c|c|}
\hline \multicolumn{5}{|c|}{$\begin{array}{c}\text { Table 1 } \\
\text { Sample Summary }\end{array}$} \\
\hline & \multicolumn{3}{|c|}{ Year } & \\
\hline & 1996 & 1997 & 1998 & Total \\
\hline Number of AAERs issued by the SEC & 76 & 95 & 79 & 250 \\
\hline Number of AAERs not sanctioning CPAs & $(45)$ & (51) & $(42)$ & $(138)$ \\
\hline Number of AAERs sanctioning CPAs & 31 & 44 & 37 & 112 \\
\hline Multiple AAERs for same violation/CPA & $(8)$ & $(11)$ & $(8)$ & $(27)$ \\
\hline AAER does not identify state of licensure & (3) & $(12)$ & $(10)$ & $(25)$ \\
\hline Number of AAERs represented in the sample & 20 & 21 & 19 & 60 \\
\hline \multicolumn{5}{|l|}{ Adjustments for: } \\
\hline AAERs reporting sanctions of multiple CPAs & 5 & 3 & 6 & 14 \\
\hline Sanctioned CPAs licensed in multiple states & 2 & 1 & 4 & 7 \\
\hline Other & $(4)$ & $(2)$ & $(2)$ & $(8)$ \\
\hline Number of State Disciplinary Actions in Sample & 23 & 23 & 27 & 73 \\
\hline
\end{tabular}

For our purposes, however, the unit of observation is not an AAER. Each AAER addresses a particular situation, such as an instance of fraudulent financial reporting. A given situation can involve multiple CPAs. Our interest is in the number of potential state disciplinary actions (i.e., the number of CPAs) in the sample. We identified 14 situations where multiple CPAs were sanctioned in a single AAER. We also identified seven situations where a given CPA was licensed in multiple states.

Information regarding state board actions was obtained via a brief questionnaire sent to each state board. All boards responded. Response time ranged from one week to six months. There were eight situations where the case was still pending before the state board or where the board indicated that it had no record of the individual having held a license. Thus, we were able to document 73 potential state disciplinary actions in our sample.

\section{RESULTS}

\section{SEC Actions}

Tables 2 and 3 describe certain characteristics of the enforcement actions contained in the AAERs. Table 2 shows a cross-tabulation between the position of the violator and whether the SEC issued a finding of fraud. We classified the violator as being either the offending corporation's employee or auditor. Nearly the same number of employees and auditors were the subject of SEC's enforcement actions. The SEC found that 32 of the 73 violators had committed fraud, in contrast to a lesser offence, such as merely a reporting violation. The finding of fraud was not independent of whether the violator was an employee or auditor. Sixty-nine percent of the employees (24/35) were deemed to have committed fraud, while only 21 percent of the auditors $(8 / 38)$ were considered to have done so. A chi-square test of the null hypothesis that the finding of fraud is independent of the violators' position can easily be rejected. This result suggests that employees perpetrated frauds and that auditors are sometimes complicit in the fraud.

\begin{tabular}{|c|c|c|c|}
\hline \multicolumn{4}{|c|}{ Table 2 } \\
\hline & Position of Violator and the Finding of Fraud by the SEC \\
\hline Position & No Fraud & Fraud & Total \\
\hline Employee & 11 & 24 & 35 \\
\hline Auditor & 30 & 8 & 38 \\
\hline Total & 41 & 32 & 73 \\
\hline
\end{tabular}

$\mathrm{X}^{2}=16.7$

$\mathrm{P}<.0001$ 
Suspension from practicing before the SEC is one of the harshest sanctions that the SEC can level against a CPA. Table 3 shows the relationship between the finding of fraud and suspension from practice. The violators in all thirty-two fraud cases were suspended, while 35 of the 41 violators found guilty of non-fraud charges were suspended. Thus, although suspensions were frequently levied in both no-fraud and fraud situations, the significant chi-square statistic indicates that suspensions were more likely in the presence of fraud. ${ }^{5}$ In all cases where the violator was not suspended, injunctions or cease and desist orders were issued.

\begin{tabular}{|l|c|c|c|}
\hline \multicolumn{5}{|c|}{$\begin{array}{c}\text { Table } 3 \\
\text { Fraud and Suspension from Practice } \\
\text { by the SEC }\end{array}$} \\
\hline & Number of Cases \\
\hline & No Fraud & Fraud & Total \\
\hline Suspension & 35 & 32 & 67 \\
\hline No Suspension & 6 & 0 & 6 \\
\hline Total & 41 & 32 & 73 \\
\hline \multicolumn{4}{|c|}{} \\
\hline $\begin{array}{l}X^{2}=5.10 \\
\mathrm{P}<.05\end{array}$
\end{tabular}

The SEC can also levy fines on violators. Fines were imposed in 14 of the 73 cases in our sample. Thirteen of those 14 cases involved fraud. The SEC clearly reserves its harshest penalties for the more serious finding of fraud.

\section{State Board Actions}

Table 4 shows that 24 of the 51 possible jurisdictions are represented in our sample. Four states (California, Florida, New York and Ohio) account for 58 percent (42/73) of the sample. Thirteen states have only one case each. Thus the incidence of SEC enforcement actions appears fairly concentrated geographically. Table 4 also shows the number of SEC enforcement actions per billion dollars of state gross domestic product. The results show that the frequency of SEC enforcement actions varies considerably by jurisdiction. It is not clear if this is due to geographic variations in SEC enforcement actions, variations in the incidence of wrongdoing, limited sample size or other factors.

The primary purpose of this paper is to assess the diligence with which state accountancy boards exercise their disciplinary powers. We defined board action to include any disciplinary action, including license revocation, license suspension, probation, fine, mandated peer review or additional continuing professional education. ${ }^{6}$ Table 4 reports the frequency of board action in each state and the percentage of cases in which each state board acted. Fifteen states acted in all of their cases. Four of these states had more than one case. Nine states did not act in all of its cases. Three of these states acted in none of their cases. Each of these states (Illinois, Nebraska and Utah) had just one case in our sample. Of the states with multiple cases, Georgia acted in only one of its three cases. Overall, state boards took action in 80.8 percent of the cases.

Table 5 reports a cross-tabulation between state board action and the finding of fraud by the SEC. The boards acted in 91 percent (29/32) of the cases involving fraud and in 73 percent (30/41) of the non-fraud cases. Although state boards acted more frequently in cases of fraud, the difference is not statistically significant at conventional levels. The three cases of non-action in instances of fraud were from California, Nebraska and Utah. As mentioned above, Nebraska and Utah had only one case in the sample. 


\begin{tabular}{|c|c|c|c|c|}
\hline \multicolumn{5}{|c|}{$\begin{array}{c}\text { Table } 4 \\
\text { State Board Actions }\end{array}$} \\
\hline State & $\begin{array}{c}\text { Number of CPAs } \\
\text { Sanctioned } \\
\text { by the SEC } \\
\end{array}$ & $\begin{array}{c}\text { Number of SEC Actions } \\
\text { per Billions of Dollars } \\
\text { of State Gross Domestic } \\
\text { Product }\end{array}$ & $\begin{array}{c}\text { Number of Board } \\
\text { Actions }\end{array}$ & $\begin{array}{c}\text { Percentage of Cases } \\
\text { where the Board Acted }\end{array}$ \\
\hline Arizona & 3 & 0.0192 & 3 & $100.0 \%$ \\
\hline California & 18 & 0.0134 & 16 & $88.9 \%$ \\
\hline Colorado & 3 & 0.0179 & 3 & $100.0 \%$ \\
\hline Florida & 8 & 0.0169 & 6 & $75.0 \%$ \\
\hline Georgia & 3 & 0.0101 & 1 & $33.3 \%$ \\
\hline Illinois & 1 & 0.0021 & 0 & $0.0 \%$ \\
\hline Maryland & 2 & 0.0107 & 2 & $100.0 \%$ \\
\hline Michigan & 2 & 0.0031 & 1 & $50.0 \%$ \\
\hline Minnesota & 1 & 0.0054 & 1 & $100.0 \%$ \\
\hline Missouri & 1 & 0.0056 & 1 & $100.0 \%$ \\
\hline Nebraska & 1 & 0.0178 & 0 & $0.0 \%$ \\
\hline North Carolina & 1 & 0.0035 & 1 & $100.0 \%$ \\
\hline Nevada & 1 & 0.0134 & 1 & $100.0 \%$ \\
\hline New Jersey & 1 & 0.0028 & 1 & $100.0 \%$ \\
\hline New Mexico & 1 & 0.0184 & 1 & $100.0 \%$ \\
\hline New York & 9 & 0.0113 & 7 & $77.8 \%$ \\
\hline Ohio & 7 & 0.0188 & 5 & $71.4 \%$ \\
\hline Oklahoma & 1 & 0.0109 & 1 & $100.0 \%$ \\
\hline Oregon & 1 & 0.0084 & 1 & $100.0 \%$ \\
\hline Pennsylvania & 2 & 0.0074 & 2 & $100.0 \%$ \\
\hline Texas & 3 & 0.0040 & 3 & $100.0 \%$ \\
\hline Utah & 1 & 0.0146 & 0 & $0.0 \%$ \\
\hline Washington & 1 & 0.0045 & 1 & $100.0 \%$ \\
\hline Wyoming & 1 & 0.0518 & 1 & $100.0 \%$ \\
\hline Total & 73 & & 59 & $80.8 \%$ \\
\hline
\end{tabular}

\begin{tabular}{|c|c|c|c|}
\hline \multicolumn{5}{|c|}{ Traud and State Board Action } \\
\hline & \multicolumn{2}{|c|}{ Number of Cases } & Total \\
\hline & No Fraud & Fraud & 59 \\
\hline Board Action & 30 & 29 & 14 \\
\hline No Board Action & 11 & 3 & 73 \\
\hline Total & 41 & 32 & \\
\hline $\mathrm{X}^{2}=3.55$ & & & \\
\hline
\end{tabular}

$\mathrm{P}<.10$

The public accountancy acts of numerous states explicitly indicate that disciplinary actions taken by other states or federal agencies constitute grounds for disciplinary action in that state. These states include California, Georgia, and Nebraska. These states collectively failed to act in five cases where the violator had been suspended from practicing before the SEC. Thus, in five situations where the state had unequivocal grounds for disciplinary action, no action was taken. Moreover, two of these cases involved fraud.

What actions do state boards take when they do act? Table 6 reports the frequency of various state board actions in the fifty-nine cases in our sample in which a board acted. Given that a board can take more than one action in a given case, the actions are not mutually exclusive, and their total exceeds 59 (i.e., the number of cases in 
which boards took action). License revocation was by far the most frequently used penalty. It is noteworthy that revocation is the most severe penalty that can be levied by a board. License suspension, the next most severe penalty, was used in only six cases. Probations and fines were each used in 16 cases. Peer reviews and other sanctions (e.g., additional continuing professional education) were used a total of 14 times.

\begin{tabular}{|c|c|c|c|}
\hline \multicolumn{5}{|c|}{ Table 6 } \\
Fraud and Type of State Board Action \\
\hline Number of Cases \\
\hline Action & No Fraud & 19 & Fraud \\
\hline Revocation & 13 & 4 & 32 \\
\hline Suspension & 3 & 6 & 16 \\
\hline Probation & 10 & 7 & 16 \\
\hline Fine & 9 & 0 & 6 \\
\hline Peer Review & 6 & 3 & 8 \\
\hline Other & 5 & 39 & 85 \\
\hline Total & 46 & & \\
\hline
\end{tabular}

As indicated in Table 5, state boards took action in 30 non-fraud cases and 29 fraud cases. The boards either revoked or suspended the violator's license in 24 of the 29 fraud cases (83 percent), and 15 of the 31 nonfraud cases (48 percent). State boards appear to use their most severe penalty relatively more frequently in cases of fraud. The less severe penalties of probation, fines and peer review were used somewhat more frequently in nonfraud cases.

An interesting issue is whether certain penalties are used in lieu of one another and whether they are used in combination with one another. In other words, which penalties do boards view as substitutes and which penalties do boards view as complements? Revocation and suspension are mutually exclusive categories, and, to a large degree, have the same effect of depriving the violator of the right to practice (at least for a period of time). Accordingly, revocation and suspension were collapsed into one category of penalty. All other penalties were collapsed into another category. Table 7 reports the results of a cross-tabulation between these two categories. The upper left to lower right diagonal reflects the number of cases where the two sets of penalties were either both used or neither used (i.e., complements). The upper right to lower left diagonal reflects the number of cases where only one of the two sets of penalties was used (i.e., substitutes). Revocations and suspensions are clearly substitutes with respect to other penalties. These penalties were only used six times in conjunction with other penalties. The significant chisquare statistic indicates that the two penalty sets are not independent of one another.

\begin{tabular}{|c|c|c|c|}
\hline \multicolumn{5}{|c|}{ Table 7 } \\
Other Penalty and Revocation/Suspension \\
\hline Other Penalty & Revocation/Suspension & Total \\
\hline Yes & 6 & No & 26 \\
\hline No & 33 & 20 & 33 \\
\hline Total & 39 & 0 & 59 \\
\hline
\end{tabular}

$\mathrm{X}^{2}=38.4$

$\mathrm{P}<.001$

\section{SUMMARY AND CONCLUSIONS}

The purpose of this paper was to document the frequency and nature of state accountancy board disciplinary actions. In order to identify a sample of situations were board action was likely to be appropriate, we identified 73 CPAs who were disciplined by the SEC during 1996-98. State boards acted in 80.8 percent of these cases. Fifteen of the 24 states in our sample acted in all their cases. Does this constitute adequate performance by 
state boards? That is a difficult question. State laws do not necessarily require the same standard of proof as do the Securities Acts of 1933 and 1934. Moreover, while substantial overlap between state and federal law exists regarding prohibited acts, the laws are not identical. Thus, valid reasons might exist for lack of board action in certain cases. Regrettably, state law confidentiality provisions prohibit state boards from commenting on cases in which disciplinary actions were not taken. Accordingly, state boards would not discuss these cases with us.

Several aspects of state board disciplinary performance were, however, rather disturbing. One state, Georgia, acted in only one of its three cases. This was the lowest percentage of action by any state with more than one case. Three states (California, Nebraska and Utah) failed to act in a case where the SEC found fraud. California had acted in numerous other cases, while Nebraska and Utah each had only one case in the sample (i.e., the one with the finding of fraud by the SEC). Perhaps the relative infrequency of cases in these states caused the boards to be inexperienced in disciplinary matters and inhibited their ability to effectively take action. Of course, the small number of cases within a given state compromises our ability to draw strong inferences.

Three states in our sample, California, Georgia, and Nebraska, have provisions in their laws indicating that grounds for disciplinary action exist when a federal agency sanctions a CPA. These three states failed to act in five cases where the SEC suspended a CPA from practicing before it. Two of these cases involved a finding of fraud by the SEC. We can think of no reasonable explanation for these state boards to have failed to act.

Although Pennsylvania had only two cases in our final sample (and acted in each of them), we identified from the AAERs three other cases involving Pennsylvanian CPAs. These AAERs were issued in 1996. The state board indicated to us that the cases were still pending, and we excluded these cases from our sample. Given that we contacted the board in the summer of 2002, these cases had been outstanding for at least four years from the time the SEC had acted. In fact, these were the only three cases in our sample that had not been resolved by the time of our data collection. It appears that the Pennsylvania state accountancy board might not have been particularly attentive to its disciplinary responsibilities.

Overall, state boards seem to be exercising their disciplinary powers in those cases where the SEC has disciplined a CPA. Protection of the public appears to be a priority for many boards. There is some evidence, however, that for a few boards their disciplinary efforts could be more forcefully exercised.

It is useful to consider further policy implications in this area. The public's interest is served when state boards discipline CPAs that have violated professional or legal standards. Timely investigation and disciplinary action by boards would help assure that others are not harmed by continued misconduct by a CPA. More importantly state board action following on SEC action would have a reinforcing effect, both on the sanctioned CPA and indirectly on CPAs in general. Adequate resources are required for effective enforcement. There is indeed reason to believe in these times that some state boards are hard pressed to devote sufficient resources to this important activity.

Coordination between state and federal regulators is also important. Basic coordination includes timely notification and sharing of information. It is also possible that investigations could be done concurrently or even jointly. Coordination is somewhat complicated by recent changes in the regulatory landscape. At the federal level the Sarbanes-Oxley Act of $2002^{7}$ among other things, established the Public Company Accounting Oversight Board (PCAOB) to oversee public company audits and the CPAs that perform them. The PCAOB is empowered to set auditing standards, conduct investigations and disciplinary proceedings, and impose appropriate sanctions. The SEC retains its power to bring actions against outside auditors and corporate accountants and is likely to continue to do so as appropriate. Thus state boards will need to establish processes, etc., whereby they effectively coordinate their enforcement activities with both the SEC and the PCAOB.

The public's trust in the accountancy profession has been eroded by the recent flurry of accounting scandals. Effective state board enforcement can help to reverse that erosion. 


\section{ACKNOWLEDGEMENTS}

We are grateful for the comments and advice of Michael MacPhail, Dennis Spackman, and Lynn Turner. Brad Billinger provided expert research assistance.

Data Availability: Contact the Authors

\section{REFERENCES}

1. American Institute of Certified Public Accountants and the National Association of State Boards of Accountancy. 1999. Uniform Accountancy Act and Uniform Accountancy Act Rules. New York, NY: AICPA/NASBA.

2. Colbert, G. J., and T. B. O'Keefe. 1995. Compliance with GAAS reporting standards: Evidence from a positive enforcement program. Auditing: A Journal of Practice and Theory 14 (Fall): 1-16.

3. Colbert, G., and D. Murray. 1998. The association between states' educational requirements and CPA exam pass rates. Research in Accounting Regulation 12: 93-108.

4. Gold, R. 2002. Andersen case poses challenge to state authorities. The Wall Street Journal January 23, A4.

5. Leob, S. E. 1972. Enforcement of the code of ethics: A survey. The Accounting Review 47 (January): 1-10.

6. Roberts R., and J. Kurtenback. 1998. State regulation and professional accounting reforms: An empirical test of regulatory capture theory. Journal of Accounting and Public Policy 17 (Autumn): 209-26.

7. Schaefer, J., and R. B. Welker. 1994. Distinguishing characteristics of certified public accountants disciplined for unprofessional behavior. Journal of Accounting and Public Policy 13 (Summer): 97-119.

8. Young, D. S. 1988. The Economic Theory of regulation: Evidence from the uniform CPA examination. The Accounting Review 63 (2): 283-91.

9. Young, D. S. 1991. Interest group politics and the licensing of public accountants. The Accounting Review 66 (October): 809-17.

\section{ENDNOTES}

\footnotetext{
${ }^{1}$ Variations in the laws of the states in our sample will be discussed in the results section.

${ }^{2}$ AAERs are available on the SEC's website, http://sec.gov/.

${ }^{3}$ The SEC uses a September 30 year-end.

${ }_{5}^{4}$ The SEC was unwilling to provide us this information.

5 Fischer's exact test, which is appropriate when expected cell sizes are small, yields substantially the same statistical conclusions in all of our tests.

${ }^{6}$ We also included in our classification of board action situations where the licensee surrendered his or her license and where the licensee failed to renew his or her license.

${ }^{7}$ There are also some states that are proposing to implement similar legislation.
} 


\section{NOTES}

